\title{
Impressions after reading a fascinating book: Bayreuth - Oraș al Festivalurilor. Prezențe românești [Bayreuth - City of Festivals. Romanian presences]
}

\author{
LOREDANA IAŢEŞEN, Associate Professor, $\mathrm{PhD}$ \\ "George Enescu" National University of Arts Iaşi \\ ROMANIA*
}

\begin{abstract}
Published in 2019 by Ecou Transilvan Publishing House, the volume Bayreuth - Oraș al Festivalurilor. Prezențe românești [Bayre uth - City of Festivals. Romanian Presences], signed by the musicologist Gheorghe Mușat has an immeasurable documentary value. From the challenge launched by the title, which is accentuated with the discovery of the differentiated perspectives for approaching the complex issue - Bayreuther-Festspiele and Internationales Jugend Festspieltreffen - to the precious details regarding the sessions, courses, seminars, concerts, conferences of artists from East and West, who had the extraordinary chance to collaborate in the last decades of the last century. In essence, the book focuses on the generation of musicians confident in the nobility of ideals to perfect themselves in the performing arts, to sing unique pieces from various stylistic repertoires and, especially, to listen, to learn from each other, to communicate at a high level about the multiple manifestation hypostases of the sound phenomenon.
\end{abstract}

Keywords: Wagner, Bayreuth, festivals, creators, musicians, concerts, universal and Romanian opuses.

The volume opens in the sensitive atmosphere of the author's confessions, based on which we get acquainted with his activity as a trumpeter and guest professor at several editions of the International Youth Festival. The image of the artist with multiple interests materializes in the suggestive commentary of the writer Hans Bergel, related to the surprising intertwining of the features of "seriousness and humor in the personality of the musician, pedagogue and writer Gheorghe Mușat" (Mușat, 2019, p. 11).

Although the table of contents is conceived in a memoir style, the reader sometimes feeling overwhelmed by the richness of the ideas to be debated, after careful reading, we find, nevertheless, a possible segmentation of the volume on several issues: "Founding the Richard Wagner Festival"; "Founding the International Youth Festival"; "On the Romanian music bands that shone in the world of the International Youth Festival of Bayreuth" and "What did the national or international newspapers write about the participating of the young Romanian musicians at Bayreuth".

\footnotetext{
*iatesenloredana@yahoo.com
} 
The first part is dedicated to the Richard Wagner Festival, where the author systematizes older and newer data about the foundation of this large event, about conductors or soloists who have asserted themselves on the big stage with Movila Verde, about traditional and innovative productions but especially about the "succession to the Festspielhaus and the Wagner family's connections with personalities of the Nazi regime" (Mușat, 2019 p. 54). A familiar, yet hardly accepted subject in the consciousness of the contemporary public. Aware of the gravity of these realities, which for a time overshadowed the legend woven around Bayreuth, the author has the courage to update the ideas of another book, L'heritage Wagner written by Gottfried, a greatgrandson of the composer, whose importance was vehemently challenged at the time of its publishing in 2001. What does this descendant of the legendary family say? "Wagner belongs to art, Hitler to the file of criminals, said Gottfried, who rejected both Wagner's cult in Bayreuth from 1872 to 1945 and the repression of the Nazi period in the New Bayreuth era" (Mușat, 2019, p. 61). The culmination of the musicological approach, focused on the affirmation and development of the festival, is the portrait dedicated to the Romanian baritone of the late nineteenth century, Dimitrie Popovici-Bayreuth, who sang under the baton of Hans Richter and Richard Strauss, and enjoyed the admiration of the Wagner family. For example, in a letter from Cosima to Gustav Mahler, we find the following: "Today, for the role of Telramund - for whom Wagner regretted all his life that he did not meet a worthy performer, as he imagined - there is no artist in the music world that can compare to Dimitrie Popovici" (Mușat, 2019, p. 70). The dense content of the ideas has a deep impact, by continuously emphasizing the significant moments of the speech with the help of conclusive documents (photos with performers or conductors, with family members from different generations, posters of shows, images from various productions). The reader is really absorbed by the vastness of the information, by the rigor of the documentation or by the dynamic style of the construction of the sentences full of meaning. There are only a few peculiarities that contribute to the creation of a coherent and provocative image of the introductory section.

In part II, focused on detailing the event Internationales Jugend Festspieltreffen, we are at the heart of the problem. We learn that at the initiative of the Finnish composer Jean Sibelius, the International Youth Festival of Bayreuth was established in 1950, held in parallel with the Richard Wagner Opera Festival (Mușat, 2019, p. 75). Thus, personalities from the international music world, assistants or professors specialized in chamber, orchestral, or opera music are invited during the three weeks, the aim being for the young musicians enrolled to participate in the concerts that mark the ending of the courses. The author reveals step by step different information about the leadership of the Youth Festival taken over by the distinguished family Herbert 
and Grete Barth, about the participants in this prestigious event at different times, about the orchestra course given by the famous conductor Erich Bergel between 1974-1980, about the programming as soloists of some musicians from Romania, about the program of concerts conducted by Erich Bergel with the International Youth Orchestra, about the delicate relationship between Erich Bergel and Cristian Mandeal. In the author's view, according to a statistic conducted at the end of the festival, we are amazed to discover that "since 1950 there have been 10459 students from 60 countries on all five continents" (Mușat, 2019, p. 85). Relevant for understanding the importance of the festival are the pages (97-130), in which Gheorghe Musat presents all the participants from the years 1975-1980 (the share of Romanian musicians being obvious). He does not limit himself only to the successive presentation of some concert programs, of some lists of names of the instrumentalists, but focuses on the commentary of the event from all perspectives. We appreciate the portraits dedicated to some performers, conductors, associated with personal observations or with extracts from musical chronicles on the proposed repertoires. For example, on the occasion of the Inaugural Concert of the Annecy - Bayreuth International Sessions, it was commented in the newspaper Le Progres, published on September 4, 1976, that together with two chamber ensembles from the Superior Conservatory of Music in Cluj, "I listened to the chamber orchestra of the Superior Conservatory of Music in Iași, conducted by Ion Baciu" (Mușat, 2019, p. 188).

The next section of the volume focuses on the "Romanian bands that shone in the world of the International Youth Festival of Bayreuth: Chamber Orchestra 'Camerata' of the Music Conservatory 'Ciprian Porumbescu' of Bucharest (conductor - Paul Staicu); Chamber orchestra 'Concerto' of the Conservatory of Bucharest (conductor - Dorel Pașcu-Rădulescu); Ensemble of wind instruments of the Conservatory 'Ciprian Porumbescu' of Bucharest (conductor - Emil Bâclea); Chamber orchestra 'Dinu Lipatti' of the Music Conservatory 'Gheorghe Dima' of Cluj-Napoca (conductor - Casiu Barbu); Chamber choir of the Symphony Hall and Conservatory of Cluj-Napoca (conductor - Florentin Mihăescu); Ensemble of wind instruments and percussion 'Aulodia' (conductor - Constantin Arcu); Music Conservatory 'George Enescu' of Iași, Chamber orchestra (conductors - Ion Baciu and Sabin Păutza); Choral 'Animosi' (conductor - Sabin Păutza); Ensemble 'Musica Viva' (conductor - Vincente Țușcă); Chamber orchestra 'Tescana' of the Symphony Hall 'Mihail Jora' of Bacău (conductor - Ovidiu Bălan)” (Mușat, 2019, pp. 193-244).

According to the author, "the first participation of the Chamber orchestra of the Conservatory of Iasi in the International Youth Festival of Bayreuth took place in August 1973, in the opening concert performing the opus Infinite Melody by Theodor Grigoriu" (Mușat, 2019, p. 226). In 1976, also under the 
conductor Ion Baciu, the opus Jocuri by Sabin Păutza was performed, and "on August 8, 1978, the Chamber Orchestra of the Music Conservatory of Iași performed the piece Vision for string orchestra by Serghei Prokofiev, conducted by Sabin Păutza in the concert at the beginning of the International Youth Festival' (Mușat, 2019, p. 227).

Each presentation of the ensembles that took part in the Youth Festival of Bayreuth is also accompanied by posters with the programs of the concerts held, from which we note the diversity of repertoires approached from a stylistic and chronological point of view. Moreover, we find that Romanian music occupied a central place in the repertoires of these bands, some opuses being played for their first audition.

Another surprise offered by the author Gheorghe Mușat is related to the systematization of the ensembles that participated in the "opening concerts of the International Youth Festival in 1973, 1975, 1978, 1980" (Mușat, 2019, p. 284). We are surprised to see that "Romania was represented by 14 bands, followed by Poland with 11 bands, Hungary with 5, Czechoslovakia with 3, Bulgaria with 3, France with 2, Finland with 2 and Norway with one band" (Muşat, 2019, p. 285). How could this phenomenon be explained? In the usual direct way, the author comments on the preponderance of musicians from the East over those from the West, from the perspective of obvious social differences, which also psychologically influenced differences in motivation "(...) From the West came those who wanted to learn and had money to pay meals, accommodation and classes. Those who came from the East did not pay for anything, they had secure accommodation, meals and also received 200 DM in order to buy the cheapest tickets to the Festspielhaus ..." (Mușat, 2019, p. 278).

Next we read about Other guests from Romania at the International Youth Festival of Bayreuth and we recognize the importance of the Chamber Music Course for brass wind instruments, held several editions by professor Gheorghe Mușat, guest of honor for this event; of professors Uzi Wiesel and Robert Hinze or the special professional relationship between Uzi Wiesel and the Voces Quartet. In this context, the author makes a special portrait of the prestigious chamber ensemble, emphasizing that during the years 1973-1974, the four members were part of the chamber orchestra of the Conservatory of Iasi invited to Bayreuth (Mușat, 2019, p. 321) and between 1978 and 1979, the Voces Quartet attended classes held in Bayreuth by Professor Uzi Wiesel. Master Uzi Wiesel's appreciation of the Voces quartet is also an emotional one: "They are dedicated musicians and wonderful performers. The Voces quartet has the appropriate talent, quality and professional attitude..." (Mușat, 2019, p. 322). Their exceptional interpretive manner in approaching the Romanian creation did not remain without echo in the international press, so that the newspaper Nordbayerischer Kurier of August 10, 1979 recorded: "at the 
opening concert of the Youth Festival, where ensembles from Poland, Romania and Czechoslovakia participated, ... Voces performed the Quartet no. 3 by Sabin Păutza, of such seductive perfection...” (Mușat, 2019, p. 322). It should be noted that between 1976 and 1978, Professor Mihail Cozmei was also invited from Iași, but unfortunately could not be present, "due to some approvals that came too late..." (Mușat, 2019, p. 296).

The last part focuses on the impact that young musicians had on the Romanian and international press. In this context we have the opportunity to reflect comparatively on the development of the event in the succession of several editions, based on the opinions of the authors who sign consistent articles in national (Făclia, România literară, Steaua, Săptămâna) or international dailies (The Times, London; Frankfurter Allgemeine, Frankfurt; Generalanzeiger, Bonn; National-Zeitung, Basel; Musik und Bildung, Mainz, Times International, Nigeria, Le Monde, Paris; Libres Belgique, Brussels).

In this section of the volume, which includes other documents (posters, photos with famous performers, letters, statements of the musicians involved in the festival), we also discover some admirable pages dedicated to a providential meeting between musician Gheorghe Mușat and trumpeter Adolf Scherbaum. The reader's emotion becomes more and more intense, when he goes through the excerpts from the correspondence between the author and Adolf Scherbaum's wife, upon his death; or with Herbert Barth, following the death of Mrs. Grete Barth. There are moments of unique sensitivity, given the special context in which the musician Gheorghe Musat found himself at that time. After the $43^{\text {rd }}$ edition of the Festival in 1983, one of the author's brothers remained in the West, so that, since 1984, the leadership of the State Security in Cluj-Napoca did not allow him to leave the country for several years. Here is one of the reasons why the perception of this artist becomes nuanced. We understand his enthusiasm when the distinguished Mrs. Sissy Thammer, in her position as general manager of the Youth Festival, extended a new invitation to participate in 1995.

What have we discovered after the 2000s? The author brings to our attention an article published in the periodical Adevărul of Cluj, under the signature of Michaela Bocu, which is a retrospective of the International Festival of Young Artists, held in Bayreuth in 2002. After being informed about a large participation of artists from 47 countries, including Romania, represented by two important chamber ensembles from the "Gheorghe Dima" Academy of Music, we are surprised by the following words: "Mrs. Thammer is a sympathizer and a sincere supporter of young musicians from Cluj, whom she prefers before others in our country..." (Mușat, 2019, p. 315). After such a subjective statement, the following question arises: how was it possible before 1989, in a political context of extreme harshness, when one of the forms of personality annihilation was the interdiction (there are many examples of artists 
who did not get the so-called approvals in time, missing significant international events), to include Romanian performers from Bucharest, ClujNapoca and Iași in the programs of the International Festival of Bayreuth, while today, when the political system no longer imposes restrictions, the access of Romanian musicians in the world becomes limited? A question whose answer is not immediately clear. We only assume that careful information and, especially, a constant collaboration of all professional music institutions, would contribute to the inclusion in the Festival programs of the Romanian representative bands from all university centers.

In conclusion, after reading this book, some ideas emerged:

The volume Bayreuth - Oraș al festivalurilor. Prezențe românești [Bayreuth City of Festivals Romanian presences] draws attention through the extensive documentation, the richness of information and the dynamism of the comments, through the direct style in the elaboration and construction of the discourse, which is fulfilled by constantly reporting to the evidence, to the testimonies of the author's analysis. Undoubtedly, the present research has the value of a reference monograph, with an encyclopedic opening of a fascinating music center, the old Bayreuth and its echoes in contemporaneity.

The author, Gheorghe Mușat, a great personality in the national and international performing sphere, proves that he is a complex musician, successfully adding to the qualities of a recognized instrumentalist or professor, that of a talented and attentive musicologist in handling all parameters of the critical apparatus (references, bibliography).

We note that Romanian musicians, performers, conductors, musicologists, who had the chance to participate in the sessions of the International Festival of Bayreuth, specialized in various courses and seminars, later capitalizing, from various perspectives, on the knowledge gained and experiences wonderful lived.

We can only congratulate Mr. Gheorghe Mușat for the effort to complete such a volume of documentary value, especially necessary in the specialized literature. We are convinced that it will become a favorite book for musicians and music lovers alike, each of the potential readers discovering fascinating ideas about the impressive work of artists admired and recognized in Bayreuth. 